\title{
Stakeholder-Based Analysis of Sustainability Report: A Case Study on Mining Companies in Indonesia
}

\author{
Dr. Ati Harmoni (Gunadarma University, Indonesia)
}

\begin{abstract}
This paper reviews the experience of the mining companie in Indonesia that publish a sustainability report. By doing such exploratory research, the study aims to contribute to the development of country-specific descriptive non financial disclosure theory by establishing a benchmark understanding of how company interpret their responsible relationship with stakeholders. Based on content analysis of the annual sustainability report, this paper provide a description of current practices current prioritization in terms of social, environmental, and sustainability disclosure themes. The results show that Indonesian mining companies share a wide range of disclosure themes in order to support relationships with their stakeholders.
\end{abstract}

\section{Introduction}

One of the main issues that emerged today is the debate on corporate responsibility to the stakeholder groups that influence their behavior and who in turn have an impact on their success. More than ten years of research by MORI has shown increasing corporate responsibility to various stakeholders, from customers and employees to legislators and investors (Dawkins and Lewis, 2003). This increases the concern that corporate responsibility issues are not confined to the public only. For many stakeholders, corporate responsibility is now the dominant driver opinions.

Corporate responsibility entails a company's recognition of broad responsibilities, that is part of society with consequent obligations, and that it should be concerned with more just profit. Concept which is currently considered to describe corporate responsibility not only in terms of profit alone is corporate social responsibility (CSR). CSR - one of the major aspects of sustainable development business, is a concept whereby companies integrate social and environment concerns into the company's business operations, as well as how they interact with stakeholders on a voluntary basis (CEC, 2001).

Along with the increasing number of companies acknowledging and internalizing the importance of CSR values and practices, a variety of sources have pressured the private sector to go beyond financial measures as all-inclusive indicators of corporate market performance. This operationally process is well represented by the large number of studies on the multiple ways of enacting CSR, which recognize the existence of a sort of parallelism between corporate socially responsible behavior and the aptitude of companies to systematically demonstrate their ability to respond to the social, economic and environmental requests of their stakeholders (Hummels and Timmer, 2004).

For these reasons, in addition to the initial trend, that is, adhering to the CSR paradigm, companies have paid growing attention to the importance of demonstrating CSR commitment through clear and verifiable data and information, similar to more traditional financial documents. Previous studies show that it is difficult for companies investing in CSR activities to maximize their reputation without disclosing information of such activities (Hasseldine et al. 2005). It is generally accepted that companies engaging in CSR activities usually concern the disclosure of related information because of its contribution to financial performance (Orlitzky et al, 2003; Barnett, 2007) or to market value (Mackey et al, 2007).

By now, research on CSR disclosure has referred to different theoretical perspectives - those of legitimacy theory, agency theory and stakeholder theory (Gray et al., 1995; Roberts, 1992). While, however, numerous studies have investigated the disclosure of nonfinancial information, only recently has research considered disclosure in a stakeholder-based setting, and extended the research focus to a more comprehensive CSRreporting framework, based on the triple bottom line approach. In other words, although the content of nonfinancial disclosure has been addressed in an increasing number of studies, the adopted perspective is often partial, impeding the development of a complete CSR portrait (Schwartz and Carroll, 2003) for firms engaged in responsible practices.

Indonesia has become the first nation in the world to introduced mandatory legal requirements for corporations to implement corporate social responsibility (CSR) reporting based on Law No. 40 in 2007 regarding Limited Liability Companies. According to this law, all corporations that operate in Indonesia's natural resources sector or that have business activities related to natural resources must implement CSR, especially in relation to environmental responsibility, called corporate social and environmental responsibility (CSER). All companies are mandated to perform the social and environmental responsibility activities and submit annually the reports of these activities. 
This study attempts to providing an up-to-date description of Indonesian companies' CSR reporting practices, how companies clearly engaged in socially and environmentally responsible practices interpret their CSR relationships with stakeholders. Hence, the remainder of this paper is organized as follows. First, we review the recent empirical evidence about sustainability reporting. Secondly the stakeholder theory and sustainability reporting are outlined with particular reference. Thirdly, the research method and data source are described. Fourthly, the findings from the study of sustainability reports are presented together with the relevant implications and concluding reflection.

\section{Stakeholder Theory and Sustainability Report}

The term 'stakeholder(s)' is broad ranging in scope. It has been defined as meaning all those individuals and groups with a 'critical eye' on corporate actors (Bowmann-Larsen and Wiggen, 2004). Freeman (1984) look at companies' responsibilities as consisting of a two-way responsibility between business and groups of stakeholders in a society. This is the stakeholder theory perspective which postulates that there are various groups in the society that an organization can impact on. These groups have a right on the organization for their interest to be addressed by the organization because of agency relationship. Business operations affect interests of multiple parties having stake in a business. Similarly behavior of multiple parties also affects business interests. Therefore businesses should incorporate stakeholder expectations into their planning and policies.

Stakeholders, acting either formally or informally, individually, or collectively, are a key element in the firm's external environment that can positively or negatively affect the organisation (Murray and Vogel, 1997). The main challenge for businesses is the task of identifying to whom they are responsible and how far that responsibility extends. Underpinning the difficulties of managing the relationship between a business and its stakeholders are issues such as divergent and often conflicting expectations between stakeholders (Brammer and Pavelin, 2004; Fairbrass, 2006); contextual complexities (Daniels and Radebaugh, 2001) that are further complicated by varying interpretations arising out of different geographical regions and cultures (Maignan and Ferrell, 2003); the challenge of identifying what might be considered to be 'best practice' with regard to CSR stakeholder dialogue strategy and then communicating this to stakeholders.

A prevalent way of exploring the roles and responsibilities of companies in today's society has been to look at them as nodes in a network of relationships among different parties that have stakes in their activities (Donaldson and Preston, 1995; Freeman, 1984). According to this theory, a principal function of managers is to handle stakeholders' needs, expectations and demands, and to manage conflicts among them. Different criteria have been suggested on how and why managers should allocate priorities to competing stakeholder views and demands, and the way to find the appropriate level of engagement.

Stakeholder theory is a fundamental element of corporate social responsibility, in the open system in which organizations interact with society; different groups with their own specific sets of needs, expectations and demands personify every interaction. CSR programs are or should be tailored around these needs in a strategic way. The impact of company's corporate responsibility program will depend on its alignment with the expectations of its various stakeholders. A Company's balancing of these several priorities must therefore be informed by its stakeholders of importance. The company must define, consult and engage these stakeholders in its program to ensure that its activity is seen as relevant both to the business and to its stakeholders, and some companies are well advanced in this process of dialogue.

Social, environmental and sustainability reports are placed in the context: 1) they substantially contribute to both formalizing firms' positions on CSR and providing a viable opportunity to assert commitment to good business practices; 2) reporting practices, that is, pulling and collecting information from business units with different priorities, represent not only a step towards evaluating and measuring the overall corporate responsibility performance, but also, and most important, a concrete opportunity to identify strengths and weaknesses across the whole spectrum of corporate responsibility (Nitkin and Brooks, 1998) and stakeholder relationships.

Sustainability reports are a modern concept of interdisciplinary reporting. They indicate the simultaneous integration of economic, environmental and social elements (Quick, 2008). After various attempts in the areas of social and environmental reporting, so-called sustainability reports have emerged in an attempt to respond to demands for interdisciplinary reporting. They reflect a simultaneous integration of economic, environmental and social factors into corporate behavior with the aim of sustaining resources for future generations.

Sustainability reporting can be explained by legitimacy theory (Gray et al., 1995). It assumes an implicit contract between companies and society. By reporting on economic, social and environmental issues a company can demonstrate that it fulfils its part of the contract and that its activities coincide with the value systems of society. This can prevent or mitigate future regulatory requirements that would constrain the strategic options of the company. Thus, the company can maintain its status and reputation in society. Instrumental stakeholder theory regards sustainability reporting as a means to address the demands of a company's stakeholders (Solomon $\&$ Lewis 2002). Following agency theory, voluntary disclosures on economic, social and environmental issues 
can decrease the information asymmetry between management and stakeholders of a company and therefore reduce agency costs. These disclosures can avoid future legislative actions against the company (Gray et al. 2001).

The benefits of sustainability reporting go beyond relating firm financial risk and opportunity to performance along environment, social and governance dimensions and establishing license to operate. Sustainability disclosure can serve as a differentiator in competitive industries and foster investor confidence, trust and employee loyalty. Analysts often consider a company's sustainability disclosures in their assessment of management quality and efficiency, and reporting may provide firms better access to capital.

Beyond the Global 250, thousands of companies around the world issue sustainability reports, and the number of companies reporting grows every year. In 2011, more than 2,200 firms filed reports with the Global Reporting Initiative (GRI), and hundreds more filed GRI-referenced reports. These firms exemplify the principle that reporting is expected of the top companies in our modern business world. Firms continuously seek new ways to improve performance, protect reputational assets, and win shareholder and stakeholder trust.

Companies unanimously state that they are reporting in order to provide information to stakeholders. When asked which stakeholders, specifically shareholders were the group most frequently referred to followed by: government and local authorities; customers; business partners; the general community and NGOs. It is clear that companies in the ASEAN region produce a Sustainability Report to gain a competitive edge when attracting and retaining capital, dealing with global clients and managing relationships with governments.

Sustainability reporting is still a relatively new process for many companies. Unsurprising therefore the collection of data for a report is the key challenge for companies. Nevertheless, companies are able to clearly articulate the benefits of reporting: to improve branding and image; and, to strengthen dialogue with stakeholders who are key to their business. For report writers there is still a huge debate about the future of sustainability reporting. For many companies reporting started as disclosure on environmental issues and has now developed into something much more encompassing. For others it began as a report on philanthropic activities and expanded to address business operations pertinent to the attainment of sustainable development.

The link between CSR strategy and sustainability reporting implies that if companies want to obtain their stakeholders' trust, they must not only communicate, but also give concrete evidence that they are committed to continual, long-term improvement. Therefore, a sustainable and responsible company must identify, measure, monitor and report all social, environmental and economic effects of its operations on society at large, in order to increase both external and internal dialogue with constituencies and improve "managerial awareness of and control over social impact of corporate activity" (Preston, 1981). As a responsible management strategy to communicate with stakeholders, the reporting of CSR is one channel by which an organization discloses how it is addressing the social, environmental and economic issues (SustanAbility/UNEP, 2002).

These points are relevant to our paper because we are interested in modeling how firms translate their perceptions of their context of reference into CSR disclosure practices. If we accept the empirical maxim that firms are what they do (Post, Preston and Sachs, 2002), CSR topics chosen for reporting provide overall insight into a company's current priorities and, particularly, its perspective on nonfinancial reporting practices. This does not imply that the opposite is true and that the absence of reporting corresponds to an absence of action.

\section{Methods}

The data for this study was collected from the sustainability report of a mining company listed in Indonesian Stock Exchange (IDX) for the year 2011, since the required data was available for this particular year. Specifically, the company chosen for the study were quoted in November 2011 - April 2012 in the selective index of the IDX, the Bisnis-27 Index. Only publicly available sustainability reports was eximined in this study. The existence of a sustainability rreport will be determined via a web-site-based survey.

The choice to focus the analysis on an Indonesian sample was based on the firm belief that the country in which the company reports influences the themes of disclosure. In other words, we believe that single elements of organizational practice cannot be considered in isolation, especially when such practices result from the context in which firms operate.

The sustainability report were analyzed using content analysis. Content analysis is appropriate in that this study dwells upon the assumption that sustainability reporting represents the most external and systematic result of company thoughts concerning responsible relationships with stakeholders. We are aware that all forms of data reaching the public domain can be considered as part of the disclosure activity of an organization. However, the choice to focus the analysis solely on sustainability reporting is justified by several reasons already highlighted in previous literature. In particular, sustainability reports help focus on a firm's CSR prioritization because managers commonly use them to signal what is important to stakeholders (Cormier et al. 2004). Even more important, sustainability reports are produced regularly, thus allowing for comparative analysis across time and space. 
The construction of categorization scheme is an essential stage in content analysis research. An interrogation instrument used in this study is adapted from a previous comparative analysis of the standard reporting tools from Tencati, Perrini, and Pogutz (2004) that are available on the market as reporting frameworks for firms who decide to disclose nonfinancial information. The interrogation instrument's categories, constructed based on the comparison among reporting standards, include the dimensions of the disclosure theme, which corresponds to seven categories of stakeholders (human resources, shareholders and the financial community, customers, suppliers, public authorities and institutions, communities and environment), a checklist for each dimension of disclosure theme, and evidence for each sub-theme included in the checklist (qualitative disclosure; quantitative disclosure; both qualitative and quantitative disclosure).

Given the recording instrument and consistent with previous literature on social and environmental reporting, the amount of disclosure per content category consists of recording whether or not a company made a disclosure in the category. At this stage, the quantification of the amount of disclosure per company is excluded.

\section{Stakeholders: Who and What Really Counts?}

The initial results showed that of the 7 companies studied, 5 of them issued sustainability reports. These 5 companies applying Global Reporting Initiatives (GRI) for their sustainability reports. Some companies indicate whether the coverage is fully, partially, or none for each indicator. Of the 5 companies analysed, 2 have $100 \%$ GRI indicator themes coverage. Table 1 breakdown the number of companies in the sample making CSR disclosures in each category themes, by stakeholders.

As shown by Table 1, the result of this empirical study is avarage degree of achievement of 84.8 per cent, which is high. This situation indicates that the companis consider important almost every stakeholder. Table 1 illustrated that the lowest number is the dimension of financial partners that just 20 per cent while other dimensions of more than 70 per cent. Highest results obtained for the environmental dimention and shareholder.

As mentioned above, according to Law No. 40 in 2007 regarding Limited Liability Companies, all corporations that operate in Indonesia's natural resources sector or that have business activities related to natural resources must implement CSR, especially in relation to environmental responsibility. The law also states that the companies must report the CSER in the annual reports and publish them publicly. The emphasis of CSER in on the issues of environmental concern, while CSR is aiming at the social responsibility activities in general. For those corporations whose business activities have a high impact on the environment, they are not only required to be responsible socially, but also environmentally through CSER.

Community concerns and shareholder rights are the most important factors that influence the companies' decision to report. Shareholders have a particularly powerful position from which to hold the company accountable on a variety of issues. The notion of shareholder democracy is a commonly discussed topic in corporate governance. The basic idea behind the term is that a shareholder of a company is entitled to have a say in corporate decisions

Human resources is a category that gets a high score. This is understandable because corporations have a strong influence on the administration of social rights of their employees, including aspects of health and safety, fair wages, education, etc. This is particularly the case in developing countries where governments have proven unwilling or unable to protect such rights, leaving it open to the discretion of corporations.

\section{Conclusion}

Interesting that in each the report are made, each company present the results of its own analysis of who their key stakeholders. In contrast to the reference made to the research instrument, the companies mentions NGO as the important stakeholders. Studies on CSR have shown that there has been increasing public pressure from bodies (such as governmental organisations, non-government organisations (NGOs), academics, trade unions and the media) for corporations to act in a socially and environmentally responsible way (Unerman and O'Dwyer, 2007). Such pressure has to some extent had an impact on CSR, as they have created a 'legitimacy gap', which provide a significant motivation for companies to engage or attempt to engage in responsible business practices in order to acquire or maintain legitimacy (Waddock, 2004). The work of NGOs and other independent pressure groups is crucial in promoting corporate disclosure, transparency and public accountability. NGOs have sought to step into the regulatory gap created by the inadequacy of both national governments and international institutions in demanding for social and environmental accounting and improved public accountability NGOs have played an increasingly significant role globally in challenging government policies and the activities of corporations with regard to abuses of human rights, environmental degradation and social unrest, including in Indonesia.

One of the key findings of this research was that Indonesian mining companies share a systematic approach to sustainability reports that address well-defined categories of stakeholders. The results also show that Indonesian mining companies share a wide range of disclosure themes in order to support relationships with their 
stakeholders in order to support relationships with their social context. Research also shows that the company considers NGOs are stakeholders who should receive attention. This provides an opportunity to conduct advanced research in the future by expanding the dimensions of stakeholders and with a greater number of companies in order to obtain a complete picture of the practice of sustainability reporting in Indonesian context.

\begin{tabular}{|c|c|c|c|}
\hline $\begin{array}{l}\text { Stakeholder } \\
\text { base category }\end{array}$ & CSR Themes & $\begin{array}{l}\text { Number of } \\
\text { companies } \\
\text { having CSR } \\
\text { Disclosure }\end{array}$ & $\begin{array}{l}\text { Percentage of } \\
\text { sample (average) }\end{array}$ \\
\hline $\begin{array}{l}\text { Human } \\
\text { Resources }\end{array}$ & $\begin{array}{l}\text { Staff composition } \\
\text { Turnover } \\
\text { Equality of treatment } \\
\text { Training } \\
\text { Working hours } \\
\text { Schemes of Wages } \\
\text { Absence form Work } \\
\text { Employees' benefits } \\
\text { Industrial relations } \\
\text { In-house communications } \\
\text { Health and safety } \\
\text { Personnel's' satisfaction } \\
\text { Workers rights } \\
\text { Disciplinary measures and litigation }\end{array}$ & $\begin{array}{l}5 \\
2 \\
5 \\
5 \\
2 \\
4 \\
2 \\
5 \\
5 \\
4 \\
5 \\
5 \\
5 \\
5\end{array}$ & 84.3 \\
\hline Shareholders & $\begin{array}{l}\text { Capital stock formation } \\
\text { Shareholders'/ } \\
\text { partners' pay } \\
\text { Rating performance } \\
\text { Corporate governance } \\
\text { Benefits and services } \\
\text { Investor relations }\end{array}$ & $\begin{array}{l}5 \\
3 \\
4 \\
4 \\
5 \\
5 \\
5\end{array}$ & 90.0 \\
\hline Customers & $\begin{array}{l}\text { General characteristics } \\
\text { Market development } \\
\text { Customer satisfaction } \\
\text { Customer loyalty } \\
\text { Product/Services information and labelling } \\
\text { Ethical \& environmental product and services } \\
\text { Promotional policies } \\
\text { Privacy }\end{array}$ & $\begin{array}{l}5 \\
3 \\
5 \\
3 \\
5 \\
3 \\
3 \\
2\end{array}$ & 72.5 \\
\hline Suppliers & $\begin{array}{l}\text { Supplier management policies } \\
\text { Contractual conditions }\end{array}$ & $\begin{array}{l}5 \\
3\end{array}$ & 80.0 \\
\hline $\begin{array}{l}\text { Financial } \\
\text { Partners }\end{array}$ & $\begin{array}{l}\text { Relations with banks } \\
\text { Relations with insurance companies } \\
\text { Relations with financial institutions }\end{array}$ & $\begin{array}{l}1 \\
1 \\
1\end{array}$ & 20.0 \\
\hline $\begin{array}{l}\text { Public } \\
\text { Authorities }\end{array}$ & $\begin{array}{l}\text { Taxes and duties } \\
\text { Relations with local authorities } \\
\text { Codes of conducts and compliance with laws } \\
\text { Contributions, benefits or easy-term financing }\end{array}$ & $\begin{array}{l}2 \\
5 \\
5 \\
4\end{array}$ & 80.0 \\
\hline Community & $\begin{array}{l}\text { Corporate giving } \\
\text { Direct contributions in the different } \\
\text { intervention fields } \\
\text { stakeholder engagement } \\
\text { Relations with the media } \\
\text { Virtual community } \\
\text { Corruption prevention }\end{array}$ & $\begin{array}{l}5 \\
3 \\
4 \\
4 \\
3 \\
3\end{array}$ & 73.3 \\
\hline Environment & $\begin{array}{l}\text { Energy consumption } \\
\text { Materials } \\
\text { Emissions } \\
\text { Environmental strategy and relations with the } \\
\text { community }\end{array}$ & $\begin{array}{l}4 \\
5 \\
5 \\
5\end{array}$ & 95.0 \\
\hline
\end{tabular}

Table 1. Incidence of CSR disclosure by stakeholder catagories and CSR themes 


\section{References}

- $\quad$ Barnett, M.L.: 2007, Stakeholder Influence Capacity and the Variability of Financial Returns to Corporate Social Responsibility, Academy of Management Review, 32(3), 794-816.

- Belkaoui, A. and P.G. Karpik: 1989. Determinants of the corporate decision to disclose social information, Accounting, Auditing \& Accountability Journal 2(1), 36-51.

- Bowmann-Larsen, L. and Wiggen, O. 2004. Responsibility in World Business: Managing Harmful Sideeffects of Corporate Activity, USA: United Nation University Press

- Brammer, S. and Pavelin, S., 2004. Building a good reputation. European Ma-nagement Journal, 22 (6), pp. 704-713.

- Commission of the European Communities: 2001, Green Paper "Promoting a European framework for Corporate Social Responsibility”, Brussels: COM(2001) 366 final.

- Cormier, D., Gordon, I.M. and M. Magnan: 2004, Corporate environmental disclosure: Contrasting management's perceptions with reality, Journal of Business Ethics 49, 143-165.

- Dando, N. and T. Swift: 2003, Transparency and assurance: Minding the credibility gap, Journal of Business Ethics 44, 195-200.

- Daniels, J. and Radebaugh, L. 2001. International Business: Environments and Operations. ${ }^{\text {th }}$ Edition, New Jersey: Prentice Hall Inc

- Dawkins, J. and S. Lewis. 2003. CSR in Stakeholder Expectations: And Their Imphcation for Company Strategy. Journal of Business Ethics 44: 185-193

- Donaldson, T. and L. Preston, 1995, The stakeholder theory of the corporation: concepts, evidence, and implications, Academy of Management Review 20, 65-91.

- Freeman, R.E.: 1984, Strategic management: A stakeholder approach, (Pitman, Boston).

- Gray, R., Kouhy, R. and S. Lavers: 1995, Corporate social and environmental accounting: A review of the literature and a longitudinal study of UK disclosure, Accounting, Auditing \& Accountability Journal 8(2), 47-77.

- Gray R. H., Javad M., Power D. M. \& Sinclair C. D. 2001. Social and environmental disclosure and corporate characteristics: A research note and extension. Journal of Business Finance and Accounting, 28 (3/4), 327-356.

- Hackston, D. and M.J. Milne, 1996, Some determinants of social and environmental disclosures in New Zealand companies, Accounting, Auditing \& Accountability Journal 9(1), 77-108.

- Hummels, H. and D. Timmer: 2004, 'Investors in need of social, ethical, and environmental information', Journal of Business Ethics 52, 73-84.

- Maignan, I. and Ferrell, O.C. 2000. Measuring corporate citizenship in two countries: the case of the United States and France. Journal of Business Ethics, 23, 283-297.

- 2003. Nature of corporate responsibilities: perspectives from American, French, and German consumers. Journal of Business Research, 56, 55

- Nitkin, D. and L.J. Brooks: 1998, 'Sustainability auditing and reporting: The Canadian experience', Journal of Business Ethics 17, 1499-1507.

- Orlitzky M. , Benjamin J.D. 2003. Corporate Social Performance and Firm Risk: a Meta-Analytic Review,

- Business \& Society, vol. 40, n. 4, 2001, pp. 369-396.

- $\quad$ Post, J.E., Preston, L.E. and S. Sachs, 2002, Managing the extended enterprise: The new stakeholder view. California Management Review 45(1), 6-27.

- $\quad$ Preston, L.E.: 1981, 'Research on corporate social reporting: Directions for development', Accounting, Organizations and Society 6(3), 255-262.

- Quick, Reiner. 2008. Voluntary sustainability reporting practices in Germany: a study on reporting quality. Contbilidade a Gestao, No 5

- $\quad$ Roberts, R.W.: 1992, Determinants of corporate social responsibility disclosure: An application of stakeholder theory, Accounting, Organizations and Society 17(6), 595-612.

- Schwartz, M.S. and A.B. Carroll, 2003, Corporate Social Responsibility: A three-domain approach, Business Ethics Quarterly 13(4), 503-530.

- SustanAbility/UNEP, 2002. Trust Us: The 2002 Global Reporters Survey of Corporate Sustainability Reporting. Engaging Stakeholder Series. SustainAbility/UNEP, London 
- Tencati, A., Perrini, F. and S. Pogutz: 2004, New tools to foster corporate socially responsible behaviour Journal of Business Ethics 53, 173-190.

- Unerman J. and B. O’Dwyer. 2007. The Business Case for Regulation of Corporate Social Responsibility and Accountability, Accounting Forum, 31: 332-353

- Waddock, S. A. 2004. Parallel Universes: Companies, Academics, and the Progress of Corporate Citizenship, Business and Society Review, 109(1): 5-42. 